\title{
Designing a Constitutional Presidential Democracy in Indonesia
}

\author{
Saldi Isra ${ }^{1}$, Fahmi Idris ${ }^{2} \&$ Hilaire Tegnan ${ }^{1}$ \\ ${ }^{1}$ Faculty of Law, Andalas University, Padang, Indonesia \\ ${ }^{2}$ Padang State University, Padang, Indonesia \\ Correspondence: Fahmi Idris, Padang State University, Padang, Indonesia. E-mail: fahmiidris.20@gmail.com
}

Received: April 2, $2020 \quad$ Accepted: May 3, $2020 \quad$ Online Published: May 13, 2020

doi:10.5539/jpl.v13n2p22 URL: https://doi.org/10.5539/jpl.v13n2p22

\begin{abstract}
The constitutional design of the Indonesian democracy has undergone several significant changes from President Sukarno's regime known as Orde Lama or the Old Order (1945-1965) to Era Reformasi or Reformation Era (1998 to present). During the drafting of the 1945 Constitution, the desire to form a democratic system of government that is unique to Indonesia has led its founding fathers to adopt an ambivalent system of government resembling both a parliamentary and presidential systems of government. By investigating the Indonesian democracy and system of government through the analysis of relevant articles of the 1945 Constitution, the present study seeks to address the question how to design a constitutional presidential democracy in Indonesia. The research results show that with the election of president and vice president and their accountability to the People's Consultative Assembly or Majelis Perwalikan Rakyat (MPR), the design of the Indonesian system of government better fits a parliamentary more than a presidential. However, the four amendments to the 1945 Constitution (from 1999 to 2002) were intended to pave the way for a presidential democracy capable of accommodating the characteristics of a true presidential system of government in Indonesia.
\end{abstract}

Keywords: constitutional presidential democracy, the 1945 constitution, presidential system, parliamentary system, people's consultative assembly, the amended 1945 constitution

\section{Introduction}

In a book entitled "Designing Democracy: What Constitution Does", Cass R Sunstein observes that the main purpose of the constitution is to allow for an effective democratic order. ${ }^{1}$ The idea behind Sunstein's claim is that the constitution is a basic frame that describes a nation's arrangement that enables democracy to work properly. A constitution gives the foundation of the government system, the form of state, and the centralregional government relationship. Given the complexity of the Indonesian democracy and system of government, it is interesting to explore its constitutional design in more detail to understand the government system. Indonesia seems to have practiced presidential democracy under two constitutions namely the 1945 Constitution signed at the dawn of Independence on August 18, 1945, and the Constitution of the Republic of Indonesia enacted in 1959. However, through a presidential decree taken by Sukarno on 5 July 1959, the 1945 Constitution was reinstated as the Indonesian Constitution.

From 1999 to 2002, this constitution has undergone four amendments that dramatically transformed the composition of the institutions within Indonesia's constitutional system. Although the substances generated by these four amendments to the 1945 Constitution are regarded as significant steps towards the democratization, they have contributed to the instability of the practice of the presidential system in Indonesia by accommodating many principles of a parliamentary system within the constitution. Although many believe that both constitutions have elements of a presidential system in common, there still exist fundamental differences between both constitutions. Therefore, the comparison of these differences justifies the assumption that the constitution is the product of the institution that makes it appropriate for social, political, and economic conditions at the time of its creation. $^{2}$

The differences in the characteristics of the government system in both the 1945 Constitution and the 1959 Constitution are not only the agreements chosen by their framers but also represent answers to socio-economic,

\footnotetext{
${ }^{1}$ See Cass R Sunstein. (2001). Designing Democracy: What Constitution Do. New York: Oxford University Press, New York, p. 6.

${ }^{2}$ See Moh Mahfud MD. (2010). Pengantar, Dalam Saldi Isra, Pergeseran Fungsi Legislasi Jakarta: Rajawali Pers, p. xxi.
} 
political and cultural problems faced by the Indonesian people. These assessments are more influenced by the dynamics of the relationship between the executive and the legislative (DPR). For example, after the amendment to the 1945 Constitution, what was achieved was a situation whereby power shifted from the Executive to the Legislative. $^{3}$ It is not surprising to often hear that the presidential system tends to be dominated by the parliament. ${ }^{4}$ The amendments to the 1945 Constitution, have been and continue to be a subject of debate and discussion among academics and politician as to what system of government was actually intended by the framers of the 1945 Constitution. Some claim that the framers intended a presidential system while of others believe that they opted for a parliamentary system.

Unfortunately, many of these critics have not been able to clearly determine whether this imbalance of power is caused by the substance or the design of presidential democracy within the constitution or the use of excessive authority by the legislative. In addition to the views above, many political parties within the legislative are giving strong support for the reinstatement of the National Guidelines of State Policies or GBHN as well as the National Development Program or Pembangunan Nasional Semesta Berencana (PNSB), which were in force under presidents Soekarno and Suharto. A return of this national policy guidelines would undeniably design the presidential democracy in the 1945 Constitution. For example, the pattern of national development, both in the form of National Planning and the National Guidelines of State Policies cannot be separated from the central role of MPR, which was stripped of much of its power in 2002 after the fourth amendment to the 1945 Constitution.

Any possible reinstatement of GBHN would reshape the Indonesian government system by repositioning MPR as the highest legislative body to which the president would be accountable. ${ }^{5}$ This paper attempts to explain the constitutional design of the Indonesian presidential democracy firstly by discussing the different classifications of democracy, secondly by explaining the concept of a government system produced by the founders of the Republic of Indonesia and thirdly, by analyzing the idea of maintaining and purifying the presidential system after the amendments to 1945 Constitution. Fourthly, the paper discusses the presidential democracy design in the 1945 Constitution as an effort towards a system of relations between the holders of legislative and executive powers (DPR and the President) in the design of checks and balances mechanisms. And finally, the paper explains how much of an impact the four amendment to 1945 from 1999 to 2002 have had on the democratization of Indonesia.

\section{Understanding Constitutional Presidential Democracy}

Legal and political sciences literature provides many classifications of types of democratic government around the world. Shugart et.al., (1992) argue that there seems to be a general agreement that there are two "pure" types of systems i.e., parliamentary and presidential and a third one that blinds elements of both - commonly called mixed semi-presidential or parliamentary-presidential systems. ${ }^{6}$ The classification discussed in this paper is not different in that it also groups democracy in Indonesia into these three categories. Our concept of constitutional presidential democracy is a combination of constitutional and democratic presidential government system whereby the authority of the majority is limited by legal and institutional means so that the rights of individuals and minorities are respected. Constitutional presidential democracy maybe understood as the type of democracy where powers of the majority are exercised a president within a framework of the constitution designed to guarantee the majority right. In Constitutional presidential Democracy, how the people are to be ruled and governed are clearly stated in the constitution, which places government authority in the executive. In This is the form of democracy practiced in the United States, South Korea, Argentina, and other countries.

Citing Juan Linz, Scott Mainwaring (1997) argues that a presidential democracy is a system of governance whereby an executive with considerable powers in the constitution and generally with full control of the composition of his cabinet and the administration is elected by the people for a fixed period of time and is not dependent on a formal vote of confidence by the democratically elected representatives in a parliament; the president is not only the holder of executive power but the symbolic head of state and cannot be dismissed, except in rare cases of impeachment, between elections. ${ }^{7}$ José Antonio et. al., (2010) in comparing presidential and parliamentary systems observe that main issue in constitutional democracy is whether the government can be

\footnotetext{
${ }^{3}$ See Hanta Yuda AR. (2010). Presidensialisme Setengah Hati. Jakarta: Gramedia, p. 4.

${ }^{4}$ See Saldi Isra. (2013). Presidential Berwajah Parlementer, dalam Media Indonesia.

${ }^{5}$ Critical notes on the plan to turn on GBHN, see, for example, Saldi Isra. (2016). Discourse on Returning to the GBHN, Kompas, Jakarta.

${ }^{6}$ See Shugart, M. S., \& Carey, J. M. (1992). Presidents and assemblies: constitutional design and electoral dynamics. New York: Cambridge University Press.

${ }^{7}$ See Juan Linz, Presidentialism, and Democracy: A Critical Appraisal Scott Mainwaring and Matthew S. Shugart. Comparative Politics Vol. 29, No. 4 (Jul. 1997), pp. 449-471
} 
removed by the assembly in the course of its constitutional term in office. Systems in which governments cannot be removed by the assembly are "presidential;" those in which they can are either "parliamentary" or, where there is a popularly elected president, "mixed" or "semi-presidential.,"

However, these attributes of democracies do not suffice to differentiate forms of governments. Uruguay is a presidential democracy that had from 1952 to 1967), a collective executive consisting of nine members from the majority and minority parties; Israel elected its prime ministers from 1996 to 2003 and yet cannot be labeled as a presidential democracy during this time since the government was accountable to the legislature; in Bolivia the president is elected by the parliament and yet it is not parliamentary since the government cannot be dismissed in the middle of its term; Venezuela prior to the 1999 constitution had a president with no constitutionally mandated powers and yet was fully recognized as a presidential democracy. ${ }^{9}$

\section{Nation Founding Ideas: A System of Its Own}

The Indonesian government system was discussed for the first time during the sessions of the Preparatory Efforts for Indonesia Independence Investigating Agency known as BPUPKI on 29 May-1 June and 10-17 July 1945. ${ }^{10}$ Radjiman Wedyodiningrat, Chairperson of the then BPUPKI, warned that the pre independence discussion should not be opper-vlakkig or superficial despite the fact that more efforts were made to deliver ideas that were only of a basic nature of government. ${ }^{11}$ When discussing the system of government during BPUPKI sessions, Soepomo wanted the composition of the Indonesian government to be formed by a consultative body system. ${ }^{12}$ Continuing Soepomo's idea, during a June 1, 1945 meeting, when proposing Pancasila, the five basic state ideologies ("philosofische grondslag" or "Weltanschauung") of an independent Indonesia, Soekarno implicitly rejected the legislative model as in the United States of America. According to Soekarno, the people's representative bodies in the US are actually not democracies but rather politieke democratie as they lack sociale rechtvaardigheid, social justice, and economische democratie. ${ }^{13}$ For Soekarno, parliamentary democracy does not guarantee Sociale Rechtsvaardigheid. On the basis of this argument, Soekarno wanted the consultative body to be formed not to only as a politieke democratie body, but also as a body that could achieve the principles of politieke rechtsvaardigheid and sociale rechtsvaardigheid at the same time. ${ }^{14}$ This means that Soekarno firmly believed that if Indonesia was to apply democracy, it should be one that reflects its own culture and beliefs, and ideologies, not the Western type of democracy. Therefore, the principle to be built is consensus and representation whereby everyone's ideas are valued and promoted in a cultural way (onverdraagzaam). ${ }^{15}$

Meanwhile, during the Great Meeting on independence and the drafting of the constitution on July 15, 1945, when conveying on the government power structure, Muhammad Yamin, one of the founding fathers, proposed that ministers be accountable to the Parliament. Echoing this idea was Mohammad Hatta, another founding father who strongly believed that it would be better if government ministers were held accountable to the people through a representative body. This idea of the founding fathers suggests the parliamentary system whereby the government is accountable to the parliament. However, taking into account the development of both the parliamentary and presidential systems in various parts of the world, Soepomo explicitly argued that an independent Indonesia needed a strong government system or, in Sukiman's view, stability as an absolute condition for building the then newly born country. ${ }^{16}$ Therefore, Soepomo stressed that the new constitution being drafted back then uses its own system of government whereby cabinet ministers are answerable to the head of the state, who in turn is not accountable to DPR but to MPR. ${ }^{17}$ These shared views of the founding fathers are still enshrined in the 1945 Constitution today.

Although the presidential system of government was preferred over parliamentary, the founding fathers did not

\footnotetext{
8 See José Antonio Cheibub et. al., (2010) Democracy and dictatorship revisited. Public Choice 143: 67. DOI: 101 DOI 10.1007/s11127-009-9491-2

${ }^{9}$ See Shugart, M. S., \& Carey, J. M. (1992). Presidents and assemblies: constitutional design and electoral dynamics. New York: Cambridge University Press.p. 80

${ }^{10}$ See Muhammad Yamin. (1956). Naskah Persiapan Undang-Undang Dasar 1945, 1st Edition (Djakarta: Yayasan Prapantja, p. 61; RM AB Kusuma. (2004). Lahirnya Undang-Undang, p. 219. See also the 1945 Constitution.

11 Ibid, p. 219

12 Ibid, p. 119

${ }^{13}$ See Yamin, Naskah Persiapan..., p. 65-81; and Kusuma. (2004). Lahirnya Undang-Undang, p. 158- 167.

${ }^{14}$ Ibid.

15 Ibid. p. 78

${ }^{16}$ See Kusuma. (2004). Lahirnya Undang-Undang., p. 309; See Yamin, Naskah Persiapan..., p. 324.

${ }^{17}$ See Yamin, Naskah Persiapan..., p. 324.
} 
opt for direct elections of legislative and executive offices. In fact, had the founding fathers preferred a parliamentary system, then the choice of the members of Parliament would be carried out through direct general elections that would give them direct sovereignty from the people. Similarly, if a presidential system was opted for then the President and Vice President and heads of regions must get their sovereignty and authority from the people who elect them in office. The first legislative elections under the 1945 Constitution were held in 1971 as per the constitution. ${ }^{18}$ As for presidential election, the unamended 1945 Constitution left it to the MPR to decide who was fit for the office. Needless to argue that this was undemocratic as the sovereign people of Indonesia were not given the chance to choose their leaders through general elections. If a pure presidential system was to apply, it would create an interdependency of legislative and executive as both have direct mandate from the very same institution-MPR. ${ }^{19}$ As stated above, the government system design intended by the founding fathers required that the executive be accountable to MPR. This implies that the President is very likely to be dismissed in the middle of his term of office by MPR.

Furthermore, it was stated in the Elucidation of the 1945 Constitution that MPR, as the then highest state institution, must set national policy guidelines for the head of state to strictly abide by in running the state. In such an arrangement, the President is nothing but the executor of the decisions of MPR. What is a president who is solely subject and dependent on the decisions and instructions of the parliament? Or what good is a president who cannot take his own decision to carry out his political agenda? This biased constitutional configuration has led MPR to impeach President Soekarno in 1967 and President Abdurrahman Wahid in 2001 for reasons that have to do with politics instead of the law. Had the concept of fixed term of office been provided for within the 1945 Constitution, both presidents would probably not have been ousted from power so easily over issues that have little to do with the law. In fact, in a presidential system with a fixed-term formula, holders of the executive branch can only be impeached if proven guilty of certain offenses clearly defined in the constitution. It is inconsistent and undemocratic to allow the legislative branch to impeach holders of the executive branch whenever it pleases as both branches received their respective mandate and sovereignty directly from the people.

The President and/or vice president should not and cannot be ousted for any reasons other than the violation of the constitution and laws. As for the ministers, the design of the 1945 Constitution placed them under the direct authority of the President who may, as his prerogative, appoint and dismiss them at his will. ${ }^{20}$ As executive power holders within the presidential system, ministers are accountable only to the president instead of the parliament as is the case in a parliamentary system. The government system designed within the 1945 Constitution by the founders has been subject to various interpretations among constitutional law scholars regarding the use of a number of presidential system characteristics, namely (1) presidential election, (2) fixed-term of office for the president who is independent on legislative confidence, and (3) the president is the head of state as well as the head of government. Aulia Rachman (2007) argues that the government system prescribed by the 1945 Constitution is a presidential system. ${ }^{21}$ In line with Rachman, in a book entitled Pengeseran Fungsi Legislatif, we argue that the government system engineered by the founders is a presidential system with more loose characteristics. These loose characters are: (1) the functions of the head of state and the head of government are carried out by the president, (2) the president cannot dissolve the Parliament, and (3) the president chooses his ministers who are accountable to him. ${ }^{22}$ Sri Soemantri, on the other hand, believes that the constitution produced by the founding fathers adheres to a mixed system of government, i.e., a combination of parliamentary and presidential systems. ${ }^{23}$

Parliamentary characteristics can be found in the Elucidation of the 1945 Constitution which says: (1) the President is elected and appointed by MPR, (2) as the holder of the highest state power, the President is the mandate of MPR, and (3) the President submits and is accountable to MPR. ${ }^{24}$ Meanwhile, the characteristics of the presidential system are provided for in Article 4 Section 1 of the constitution, which stipulates that government power lies in the hands of President. The characteristics of the presidential system are also furthered by Article 17 of the 1945 Constitution, which says that the appointment and removal of ministers is at the

\footnotetext{
${ }^{18}$ See Article 19 Section 1 and 2 of the 1945 Constitution.

19 See Alfred Stepan and Cindy Skach. (1993). Constitutional Frameworks and Democratic Consolidation: Parliamentarianism and Presidentialism. World Politics, Vol. 46, No. 1, p. 4.

${ }^{20}$ See Article 17 of the 1945 Constitution.

${ }^{21}$ See Aulia A Rachman. (2007). Sistem Pemerintahan Presidensil Sebelum dan Sesudah Perubahan UUD 1945: Studi Ilmiah tentang Tipe Rezim, Tipe Institusi, dan Tipe Konstitusi", Doctoral Dissertation, Faculty of law, Universitas Indonesia, Jakarta, p. 145.

22 See Saldi Isra. (2010). Pergeseran Fungsi Legislaif, pp. 52-53

${ }^{23}$ See Sri Soematri. (1993). Tentang Lembaga-lembaga Negara Menurut UUD 1945. Bandung: Citra Aditya Bhakti, p. 115.

${ }^{24}$ See Sri Soemantr. (1976). Sistem-sistem Pemerintahan Negara-negara Asean. Bandung: Tarsito, pp. 52-53.
} 
disposal of the president. ${ }^{25}$ Explaining the design of the government system in the 1945 Constitution, I Made Leo Wiratama (2006) observes that when drafting the Indonesian 1945 Constitution-BPUPK and PPKI had a very long and complex debate over the determination of the post-independence government system in Indonesia. This is due to the bitter experience of the Indonesian people after being colonized for over 350 by the Dutch.

Despite efforts to set up a typical independent Indonesian government system, Western influence remains significant. The dilemma between the desire to apply Western systems of government and a system that is typical to Indonesia eventually gave birth to an ambiguous system of government. ${ }^{26}$ However, arguing that the founding fathers have intended a presidential system of government would be a misleading conclusion to reach. Rachman, for example, believes that the fact that general elections are held in Indonesia suffices to say that the government system is presidential. This view does not take into consideration the fact that in a true presidential system, the President is not accountable to any people's representative institution. Although some characteristics of the presidential system such as the minister being appointed and accountable to the president and the lack of separation of position between the head of state and the head of government, it is hard to believe that a presidential system is what the founding fathers intended when they drafted the 1945 Constitution.

The belief that a presidential system is the original intent of the 1945 Constitution ignores two main characteristics of the presidential system itself. First, the requirement that the holders of legislative power and those of the executive power get their mandate directly from the people through general elections. In fact, the 1945 Constitution does not explicitly regulate general elections as usually does the constitution in countries that have embraced the presidential system. Even if general elections were held during President Suharto's New Order, they were only meant for electing law makers. Second, the president is accountable to the legislative body, in this case, responsible to MPR as the supreme authority of popular sovereignty. According to Giovanni Sartori (1997), a government system can be said to comply with the presidential democracy if the president is elected through popular election, irremovable by the parliament, and appoints and removes cabinet members. Consequently, we agree with Andrew Ellis when he argues that Indonesia is far from meeting the criteria for a presidential system with regard to the unamended 1945 Constitution, ${ }^{27}$ but rather the parliamentary system.

Another element that proves that a parliamentary system of government was intended by the founding fathers is the proposal of the Indonesian National Working Committee or BP KNIP, which was in favor of a system of government whereby the executive together with the ministers is accountable to the parliament. After the reception of the proposal from BP KNIP on November 14, 1945, the cabinet under the leadership of President Soekarno shifted into a parliamentary cabinet led by Sutan Sjahrir as the Prime Minister. Reasonably speaking, if a presidential system is what was intended by the founding fathers, then the change of the government system, as a consequence of the proposal of the BP KNIP, should have been through an amendment to the 1945 Constitution. Without such an amendment, it would be difficult to ascertain that the founding fathers intended a presidential system in Indonesia.

\section{Purification of the Presidential System}

Amending the 1945 Constitution was one of the demands of the Reformation Era (Era Reformasi). ${ }^{28}$ In order to carry out the demands for reformation, fundamental changes to the constitution were made to the 1945 Constitution within a four-year period (1999-2002). In a speech delivered on August 10, 2002, MPR Chair Amien Rais stated that the results of the four changes to the constitution were like a big leap for the future of the Indonesian people. ${ }^{29}$ Among the big leaps that Amien Rais meant was the redesign of the Indonesian government system. According to Rachman (quoted earlier), there are at least five reasons for MPR to maintain a presidential system: (1) the choice of a presidential system as an agreement based on the beliefs and interests of the founding fathers, even though the design looks more like a parliamentary system; (2) Indonesia has had a traumatic experience with parliamentary system; (3) a parliamentary system is considered a liberal democratic school of thought; (4) a presidential system is believed to create government stability; and (5) direct elections

\footnotetext{
${ }^{25}$ See Soemantri, Sistem-sistem Pemerintahan. pp.52- 53.

${ }^{26}$ See I Made Leo Wiratama. (2006). Purifikasi Sistem Presidensil, dalam Indra J Piliang and TA Legowo (eds.), Disain Baru Sistem Politik Indonesia Jakarta: CSIS, p. 26.

${ }^{27}$ See Andrew Ellis. (2002). The Indonesian Constitutional Transition: Conservatism or Fundamental Change. Singapore Journal of International and Comparative Law, No. 116, p. 17-18.

${ }^{28}$ The Post-Soeharto Era or Reform Era in Indonesia began in mid-1998, precisely when President Soeharto resigned on May 21, 1998, and was replaced by Vice President BJ Habibie.

${ }^{29}$ See Kompas, 12 August 2002.
} 
strengthen the legitimacy of the government because it has a direct mandate from the people. ${ }^{30}$ By reading all the contents of the change, especially those directly related to the holders of both legislative and executive powers and the relations between the two, one can notice that the choice of a presidential system is followed by efforts to erode the elements of the parliamentary system. In other words, the constitution was amended to accommodate the characteristics of a presidential system according to Giovanni Sartori's analysis mentioned above. These efforts are known as "presidential system purification".

The step towards purification is carried out in the form of (i) choosing the president/vice president through direct elections by the people; (ii) rearranging the position of MPR and removing presidential / executive accountability to representative institutions; and (iii) clarify the mechanism of impeachment of the president / vice president. First, the purification of the method of electing the President/Vice President. Although in 1999, the electoral process was carried out by MPR, it was not democratic as argued earlier. Not only does this system provide a broad opportunity for the people to make choices directly, but it is also evidence of the direct mandate and real support of the people. In this sense, direct elections can allow for checks and balances between the executive and the legislative. ${ }^{31}$ Second, concerning the rearrangement of MPR. As argued earlier, prior to the amendments to the 1945 Constitution, MPR was the highest state institution (die gesamte Staatsgewalt liege allein bei der Majelis). But, as part of the presidential system purification, the 1945 Constitution of the Republic of Indonesia relegated MPR to a mere state institution and stripped it of much of its powers in order to get out of the trap of the ambiguous administrative design in creating checks and balances between state institutions. MPR was not only stripped of its powers, but it was also restructured to include members of DPR and DPD elected through general elections. ${ }^{32}$ These fundamental changes were meant not just to reduce the hegemony of MPR but also to place it in equal position with other state institutions.

In Democracy and Dictatorship Revisited, Jose Antonio Cheibub et.al., argue that the answer to whether a country's democracy is either a parliamentary system or presidential system lies in the following questions: is the government accountable to the legislative? If the answer is "no" then the design is a presidential system. ${ }^{33}$ If a similar answer applies to Indonesia, then it adheres to a presidential system. Four presidents-Soekarno, Soeharto, BJ Habibie, and Abdurrahman Wahid were the first victims of such unclear terms and mechanisms of impeachment in the unamended 1945 Constitution. Without clear arrangements and processes, such efforts can potentially lead to a form of parliamentary cabinet accountability and can disrupt efforts to create a stable government. ${ }^{34}$ To avoid such obscurity, the amended 1945 Constitution has made the terms of impeachment clearer and more complex.

The terms and conditions for impeachment within the amended 1945 Constitution are broader than those contained in the US constitution whereby the requirements are clearer and more concrete. As argued earlier, presidents Soekarno, Soeharto, BJ Habibie, and Abdur-Rahman Wahid were the victims of the elucidation of the 1945 Constitution which only states that DPR can always supervise the actions of the President and if it considers the President to have infringed the provisions set by the constitution or by MPR, it can initiate the impeachment process. Additionally, the impeachment process within the amended 1945 Constitution is not only subject to a political mechanism, but it also undergoes a legal assessment at the Constitutional Court. It is worth noticing no President has been impeached before the end of their term ever since these reforms were made to the 1945 Constitution. The reason for this stability is that the amended constitution no longer provides any basis for impeaching holders of the executive branch for political motives. Impeachment can only be done in a layered process and requires a very long time. Therefore, the President and/or the Vice President need not be pressured by the political upheaval in the use of the supervisory oversight function vested in DPR To maintain the balance of power, the 1945 Constitution also explicitly stipulates that the President cannot dissolve DPR. ${ }^{35}$ This is the result of President Sukarno's attempt to dismiss the Parliament through a presidential decree on July 5, 1959, because it rejected the 1960 state budget proposal submitted by the government. A similar experience was repeated when President Abdurrahman Wahid attempted to freeze MPR and DPR via a presidential decree dated July 23, 2001, when he was threatened with impeachment from MPR. These provisions are designed to

\footnotetext{
${ }^{30}$ See Rachman, "Sistem Pemerintahan...”, p. 378- 380.

${ }^{31}$ See Saldi Isra. (2001, September). Pemilihan Presiden Langsung”. Kompas.

32 See Article 1 Section 2 of the 1945 Constitution of the Republic of Indonesia.

${ }_{33}$ See Jose Antonio Cheibub, Jennifer Gandhi, and James Raymond Vreeland. (2010). Democracy and Dictatorship Revisited. Journal of Public Choice, p. 81.

${ }^{34}$ See Bagir Manan. (1999). Lembaga Kepresidenan. Yogyakarta: Gama Media, p. 113.

${ }^{35}$ See Article 7C of the 1945 Constitution of the Republic of Indonesia.
} 
strengthen democracy by purifying the presidential system in Indonesia.

\section{Checks and Balances between the Executive and the Legislative}

As stated at the outset of this paper, one of the objectives of constitutional reform (1999-2002) is to "improve the basis for a democratic administration of the state through a stricter power sharing, a more rigorous system of checks and balances and transparency, and the formation of new institutions to meet the nation's needs and challenges. The pattern of the relationship between the legislative and Executive in the amended 1945 Constitution is aimed at establishing the design of checks and balances as both are directly elected by the people. As argued by Juan Jose Linz (1997), one of the positive characteristics attributed to presidentialism is accountability and identifiability. There are at least two patterns of relations between the two institutions based on the constitutional functions of DPR.

First, the Legislative Function. The amended 1945 Constitution prescribes that legislative authority is vested in the hands of DPR and the President. This gives both branches equal authority to make the law. This could be interpreted as a form of checks and balances between DPR and the President in the legislative function. Djayadi Hanan (2010) argues that Article 20 Section 2 and 3 of the 1945 Constitution unite both DPR and the President through deliberation in joint discussions and mutual agreement.

Second, the Supervisory and Budgetary Functions. The 1945 Constitution through its Article 20A Section 2 prescribes that DPR has the right to interpellate, to enquire, and to express opinions over the state budget. This provision also prescribes that DPR can approve/disapprove not only the Draft Law on State Budget (proposed by the President) but also the Regional Representative Council's consideration of the Draft Law on State Budget and Draft Law concerning tax, education, and religion. DPR is also vested with the power to approve/disapprove the transfer of state assets that have broad impacts on the people's lives. This constitutional provision places DPR as the watchdog of both the President and the government over budgetary issues. This sometimes leads to tension between the legislative and the executive.

Nevertheless, in a presidential system, it is certainly not easy to build a pattern of institutional relationship that has no tension at all. The situation can get more complicated if the presidential system is built on a multi-party system lacking the management of political parties in parliament. But no matter how worse it gets, the relationship that emerges between the DPR and the government is meant to ensure balance and accountability as the constitutional design of the budgetary function gives a larger portion to the executive power holders. In fact, the draft law on the state budget for revenues and expenditure or Anggaran Pendapatan dan Belanja Negara (APBN) can only be submitted by the president. This design is different from the draft non-state budget law, which limits the authority of DPR only to conduct joint discussions and agreements to allow for checks and balances. Should DPR fail to approve the draft budget, the 1945 Constitution provides a way out through its Article 23 section 3, which prescribes that "if DPR does not approve the draft state budget and expenditure proposed by the President, the government can operate with the budget of the previous year". This design is also intended to allow for checks and balances mechanism and therefore there is no need to worry that the country might run out of budget someday because DPR has disapproved the government's budget proposal. Third, the Supervisory function. The overall discussion above endeavored to explain what type government system was meant by the Orde Lama (the Olde Order), the Orde baru (the New Order) and the Era Reformasi (the Reformation Era) under respectively the 1945 Constitution and the Amended 1945 Constitution of the Republic of Indonesia.

We have argued that with no direct election of president/vice president and the chief executive accountable to the People's Consultative Assembly or Majelis Perwalikan Rakyat (MPR), the design of the Indonesian system of government is closer to a parliamentary system than a presidential system. However, how much of an impact the four amendments to the 1945 Constitution have had on the democratization of the Republic of Indonesia is worth discussing.

\section{Constitutional Reforms and the Democratization of Indonesia}

Preamble to the 1945 Constitution of the Republic of Indonesia says that to form a government which shall protect all the people of Indonesia, the independence and the land that has been struggled for, and to improve public welfare, to educate the people and to contribute in the establishment of a world order based on freedom, perpetual peace and social justice, the independence of Indonesia shall be formulated into a constitution of the Republic of Indonesia which shall be built into a sovereign state based on a belief in the One and Only God, just and civilized humanity, the unity of Indonesia, and democratic life led by wisdom of thoughts in deliberation amongst representatives of the people, and achieving social justice for all the people of Indonesia. These five ideologies (the belief in one and only God, a just and civilized humanity, unity, democracy, and social justice) are 
the core foundation of the Indonesian State and they are enshrined in a national doctrine known as Pancasila (the five pillars).

However, just because the constitution says the state shall be based on "five pillars" including democracy does not necessarily mean the concept should be taken for granted, that is to assume that Indonesia is automatically a democracy. Where the right to individual freedom is a result deduced from the principles of the constitution, chances are that the right is capable of being suspended or taken away. The advent of concepts such as democracy the rule of law has never been the result of some government declarations and regulations, instead, it is the result of a long struggle between ruler and subjects. ${ }^{36}$ The four amendments to the Indonesian 1945 Constitution (1999, 2000, 2001, and 2002) may suffice as evidence of the perpetual struggle of the Indonesian people toward social justice and democracy. These amendments essentially deal with two issues i.e., democracy and the rule of law. The present discussion only focuses on the former. It worth noting that it was until these four amendments were made to the 1945 Constitution that democracy really started to take shape in Indonesia. ${ }^{37}$ As stated earlier, the concept of a fixed term of office has not been applied properly in Indonesia until the amendment of the 1945 Constitution.

For more than half a century, Indonesian Presidents were chosen by the People's Consultative Assembly or the Majelis Permusyawaratan Rakyat (MPR) staffed with both members of the People's Representative Council or Dewan Perwakilan Rakyat (DPR) and the members of the Council of Representatives of the Regions or Dewan Perwakilan Daerah (DPD) who have been elected through general elections. ${ }^{38}$ This political system is known as Parliament Democracy whereby the Legislative elects the Head of the State instead of a direct election. Although Parliament Democracy sounds democratic, it was not really representative under President Suharto's Administration as both the DPR and DPD were staffed by either military officers accountable to no one but Suharto himself or by members of his own political party- the Functional Groups or Golongan Karya (Golkar) which was the only political party allowed by Suharto since he banned all the other rival political parties. ${ }^{39}$ Suharto was not really elected since he controlled the MPR, the Indonesia supreme legislative body that elected the President. ${ }^{40}$ Unable to question Suharto, all MPR had to do was to give him a free pass each time his term came to an end as pointed out by Herbert Feith. ${ }^{41}$ Feith describes this as an "indecorous pressuring of parliament. No wonder Suharto remained President of Indonesia for more than three decades.

However, it was not until 2004 that parliament democracy was terminated by a constitution amendment. In fact, Article 6A (1) of the 1945 Constitution stipulates that the President and Vice-President shall be elected as a single ticket directly by the people. As a result of this turn of events, Indonesia held her first democratic presidential election in 2004 which was won by President Susilo Bambang Yudhoyono. The changes do not stop there. Other crucial reforms brought by the amendments are the limitations placed upon the president as some of his/her actions and term in office as argued earlier. This constitutional provision also helps protect the Legislative from the abuse of the Executive, thus guaranteeing the separation of powers. In fact, Article 7 goes further in its section C to say that the President may not freeze and/or dissolve the DPR. This most certainly helps secure democracy and the rule of law in Indonesia. Up-to-date, Indonesia has successfully held four democratic presidential elections $\left(2004,2009\right.$, 2014, and 2019). ${ }^{42}$ As Juan Jose Linz (1964) argues, in the process of constitutional innovation in countries that traditionally have had a presidential constitution, or where an authoritarian regime enacted such a constitution, the transition to democracy takes place through the free election of a new president.

\section{Conclusion}

Generally understood, the government system, in a democracy, is a system that regulates the relationship between the holders of legislative power and those of executive power. By using this simple understanding, the design of the 1945 Constitution of the Republic of Indonesia actually has provided a strong foundation for the

\footnotetext{
${ }^{36}$ See Hilaire Tegnan (2016). The Implementation of the Rule of Law in Post-Colonial Developing Countries: A Case Study of Legal Pluralism in Indonesia. Ph.D Dissertation, Faculty of Law, Andalas University Depository. pp.206-207

37 Ibid. p-206

${ }^{38}$ See Article 2 of the 1945 Constitution of the Republic of Indonesia

${ }^{39}$ See Hilaire Tegnan (2016). The Implementation of the Rule of Law in Post-Colonial Developing Countries: A Case Study of Legal Pluralism in Indonesia. Ph.D Dissertation, Faculty of Law, Andalas University Depository. pp.206-207

40 Ibid.

${ }^{41}$ See Herbert Feith, Suharto's Search For a Political Format, Australia's Neighbours, May-June 1968

${ }^{42}$ See Hilaire Tegnan (2016). The Implementation of the Rule of Law in Post-Colonial Developing Countries: A Case Study of Legal Pluralism in Indonesia. Ph.D Dissertation, Faculty of Law, Andalas University Depository. pp.206-207
} 
operation of the presidential system, especially the relationship between the executive and the legislative. Tensions sometimes arise between DPR and the President in the implementation of the presidential system not because of weak constitutional design, but rather due to practical issues. These tensions are normal as the presidential system is a government mechanism that seeks to build a balance between the executive and the legislature. At first, the constitutional democracy provided for within the amended 1945 Constitution seems to limit the authority of the president and strengthen that of the Parliament. But when one takes a closer look at the substantial articles, the position of the President is not any weaker than that of DPR in terms of the legislative, supervisory and budgetary functions. In fact, the amendments to the 1945 Constitution have made the president far more protected against DPR in term of impeachment. Such a safe position granted to the president creates a presidential system to ensure checks and balances and to prevent the return of authoritarian regimes. Besides strengthening the presidential system without completely weakening the parliamentary system of government, the 1945 Constitution also paved the way to the implementation of democracy and the rule of law in Indonesia through the four amendments that took place in 2001, 2002, 2003, and 2004). Given its functioning mechanisms, and regardless of a couple of parliamentary design characteristics, the Indonesian government system is best fitted for a constitutional presidential democracy built upon national ideology/doctrine such as Pancasila.

\section{Acknowledgement}

We are grateful to Padang State University and Andalas University, especially, the Faculty of Law and its Center for Constitutional Studies or Pusat Study Konstitutsi (PUSaKO) for support leading to the completion of the study. Both Prof. Saldi Isra and Dr. Hilaire Tegnan can be contacted through the following e-amail: saldiisra@law.unand.ac.id

\section{References}

Alan, R. B., \& Peters, B. G. (2000). Modern Politics and Government (6th ed.). London: Macmillan Press Ltd.

Aulia, A. R. (2007). Sistem Pemerintahan Presidentil Sebelum dan Sesudah Perubahan UUD 1945: Studi Ilmiah tentang Tipe Rezim, Tipe Institusi, dan Tipe Konstitusi. Doctoral Dissertation. Faculty of Law, University of Indonesia, Jakarta.

Cheibub, J. A. (2010). Democracy and Dictatorship Revisited. Journal of Public Choice. https://doi.org/10.1007/s11127-009-9491-2

Ellis, A. (2002). The Indonesian Constitutional Transition: Conservatism or Fundamental Change. Journal of International and Comparative Law, (116).

Feith, H. (1968, May-June). Suharto's Search For a Political Format. Australia's Neighbours. https://doi.org/10.2307/3350713

Hanan, D. (2010). Menakar Presidensialisme Multipartai di Indonesia. Jakarta: Mizan.

Hanta, Y. A. R. (n.d.). Presidensialisme Setengah Hati. Jakarta: Gramedia.

Indrayana, D. (2007). Mendesain Presidensial yang Efektif: Bukan "Presiden Sial" atawa "Presiden Sialam", Conference Paper, Bukittinggi.

Isra, S. (2001, September 24). Pemilihan Presiden Langsung, Kompas, Jakarta.

Isra, S. (2010). Pergeseran Fungsi Legislasi. Jakarta: Rajawali Press.

Isra, S. (2013, December10). Presidensial Berwajah Parlementer, dalam Media Indonesia.

Isra, S. (2016, January 12). Wacana Menghidupkan GBHN, Kompas, Jakarta.

Kusuma, A. B. (2004). Lahirnya Undang-Undang Dasar 1945. Faculty of Law University of Indonesia Press.

Linz, J. (1997, July). Presidentialism, and Democracy: A Critical Appraisal Scott Mainwaring and Matthew S. Shugart. Comparative Politics, 29(4), 449-471. https://doi.org/10.2307/422014

Manan, B. (2003). DPR, DPD, dan MPR dalam UUD 1945 Baru. Yogyakarta: Faculty of Law Universitas Islam Indonesia Press.

Moh, M. M. D. (2010). Pengantar, dalam Muhammad Yamin (1959). Naskah Persiapan Undang-Undang Dasar 1945, 1st Edition Jakarta: Yayasan Prapantja.

Sartori, G. (1997). Comparative Constitutional Engineering: An Inquiry into Structures, Incentives and Outcomes Washington Square, New York University Press.

Satriawan, I. (2003). Impeachment in Indonesia and the United States: A Comparative Study. Master Degree 
Thesis, International Islamic University, Malaysia.

Shapiro, R. Y. (2000). Presidential Power: Forging the Presidency for the Twenty- First Century. New York, Chichester, West Sussex: Columbia University Press. https://doi.org/10.7312/shap10932

Shugart, M. S., \& Carey, J. M. (1992). Presidents and assemblies: constitutional design and electoral dynamics. New York: Cambridge University Press. https://doi.org/10.1017/CBO9781139173988

Soematri, S. (1976). Sistem-sistem Pemerintahan Negara-negara Asean Bandung: Tarsito.

Soematri, S. (1993). Tentang Lembaga-lembaga Negara Menurut UUD 1945. Bandung: Citra Aditya Bhakti.

Stepan, A., \& Skach, C. (1993). Constitutional Frameworks and Democratic Consolidation: Parliamentarianism and Presidentialism, Journal of World Politics, 46(1). https://doi.org/10.2307/2950664

Sunstein, C. R. (2001). Designing Democracy: What Constitution Do. New York: Oxford University Press, New York.

Suny, I. (1977). Pergeseran Kekuasaan Eksekutif: suatu penyelidikan dalam hukum tatanegara. Jakarta: Aksara Baru.

Tegnan, H. (2016). The Implementation of the Rule of Law in Post-Colonial Developing Countries: A Case Study of Legal Pluralism in Indonesia. Ph.D Dissertation, Faculty of Law, Andalas University Depository.

The 1945 Constitution of the Republic of Indonesia.

The 1959 Constitution.

Wiratama. I. M. L. (2006). Purifikasi Sistem Presidensiil. Indra J Piliang dan TA Legowo (eds.), Disain Baru Sistem Politik Indonesia Jakarta: CSIS.

Yamin, M. (1959). Naskah Persiapan Undang-Undang Dasar 1945 (1st ed.). Djakarta: Yayasan Prapantja.

\section{Copyrights}

Copyright for this article is retained by the author(s), with first publication rights granted to the journal.

This is an open-access article distributed under the terms and conditions of the Creative Commons Attribution license (http://creativecommons.org/licenses/by/4.0/). 